\title{
Obesity, Prejudice, Self, and Culture: A Longitudinal Case Study
}

\author{
Milena Oliveira da Silva ${ }^{1}$ (D) https://orcid.org/0000-0001-5901-1474 \\ Angela Uchoa Branco ${ }^{2}$ (D) https://orcid.org/0000-0002-6127-1707
}

\begin{abstract}
With the increasing number of obese individuals in Brazil, the importance of studies aimed at researching the social and psychological impact of obesity is also increased. This study aimed to trace and analyze the processes of subjective construction of the obesity experience. This is a longitudinal case study with a 29 -year-old obese woman submitted to bariatric surgery. The characteristics and power of explicit and implicit messages that operate in specific cultural contexts were investigated, analyzing the construction of meanings of self in the development of the dialogical self. Qualitative data analysis shows important aspects of the dynamics of fatphobia, its power to channel the subjective trajectory of the obese subject and the importance of alterity in the development of self. The study contributes to the advancement of knowledge about the relations between obesity, self, and prejudice, seeking to provide inputs for the performance of psychologists, educators, and health professionals.
\end{abstract}

Keywords: obesity, culture, prejudice, self representation

\section{Obesidade, Preconceito, Self e Cultura: Um Estudo de Caso Longitudinal}

Resumo: Com o número crescente de obesos no Brasil aumenta também a importância de estudos dedicados à investigação do impacto social e psicológico da obesidade. Esse estudo objetivou identificar e analisar os processos de construção subjetiva da experiência de obesidade. Trata-se de um estudo de caso longitudinal com uma mulher obesa de 29 anos submetida à cirurgia bariátrica. Foram investigadas as características e poder das mensagens explícitas e implícitas que operam em contextos culturais específicos, analisando a construção de significados de si no desenvolvimento do self dialógico. A análise qualitativa dos dados revela aspectos importantes da dinâmica da gordofobia, seu poder de canalização da trajetória subjetiva do obeso e a importância da alteridade no desenvolvimento do self. O estudo contribui com o avanço do conhecimento sobre as relações entre obesidade, self e preconceito, buscando oferecer subsídios para a atuação de psicólogos, educadores e profissionais de saúde.

Palavras-chave: obesidade, cultura, preconceito, representações de si

\section{Obesidad, Prejuicio, Self y Cultura: Un Estudio de Caso Longitudinal}

Resumen: Con el creciente número de obesos en Brasil, también hay un incremento de la importancia de estudiar el impacto social y psicológico de la obesidad. Este estudio propone identificar y evaluar los procesos de construcción subjetiva de la experiencia de obesidad. Se trata de un estudio de caso longitudinal en el cual participó una mujer obesa de 29 años sometida a la cirugía bariátrica. Se investigaron las características y el poder de los mensajes explícitos e implícitos que operan en contextos culturales específicos, analizando la construcción de significados de sí mismo en el desarrollo del self dialógico. El análisis cualitativo de los datos reveló aspectos importantes de la dinámica de la fobia a la gordura, su poder de concentración en la trayectoria subjetiva del obeso y la importancia de la alteridad en el desarrollo del self. El estudio contribuye a ampliar el conocimiento sobre las relaciones entre obesidad, self y prejuicio, buscando ofrecer aportes para el trabajo de psicólogos, de educadores y de profesionales de salud.

Palabras clave: obesidad, cultura, prejuicio, representaciones del si mismo

${ }^{1}$ Centro Universitário de Brasilia, Brasília-DF, Brazil

${ }^{2}$ Universidade de Brasilia, Brasilia-DF, Brazil

Article derived from the doctoral thesis of the first author under supervision of the second author, defended in 2017, in the Graduate Program in Processes of Human Development and Health, Institute of Psychology, University of Brasilia. Support: Coordenação de Aperfeiçoamento de Pessoal de Nível Superior (CAPES/DS e CAPES/Programa de Doutorado Sanduíche no Exterior - Processo 99999.003672/2015-08).

Correspondence address: Milena Oliveira da Silva. Centro Universitário de Brasília. Faculdade de Ciências da Educação e Saúde - FACES. Psychology Program - SEPN 707/907 - Campus Universitário - Asa Norte. Brasília-DF, Brazil. CEP. 70.790-075. E-mail: milenaoliv@gmail.com
Constituting oneself is a dynamic process that never ends. What leads us to be how we are? The continuous challenge for the socio-cultural and dialogical approaches to human life is to understand how singularity is built, the originality of the trajectories of life that occurs in cultural and social environments permeated by redundant and powerful affective-semiotic messages, which act on the processes of cultural channeling, or of directing personal paths (Gillespie \& Zittoun, 2015; Zittoun \& Cerchia, 2013; Zittoun et al., 2013). In the specific case of obese people, 
what kind of cultural messages are they receiving? How do fatphobia experiences impact the development of self?

In this article, we selected for presentation a case study conducted in the context of a broader doctoral research, involving other case studies with obese women, over a period of two years. Data obtained in case studies, once constructed and analyzed, can serve as a basis for tracing processes capable of being generalized to other subjects and contexts, as advocated by the theorists and researchers who use case studies as research method (Camic, Rhodes, \& Yardley, 2003; Chen \& Pearce, 1995; Salvatore, Valsiner, Simon, \& Gennaro, 2010). In the specific case, we analyze the dynamics of fatphobia in the context of our culture, and how this can exert the cultural channeling on the subjective trajectory of obese people.

Obesity, defined as a condition of abnormal or excessive accumulation of fat in the body, which may be deleterious to the individual's health, is considered a multifactorial disease. The development of obesity occurs due to multiple interactions between genes and environment. The etiology of obesity is not easily traced because it results from a complex interaction between behavioral, cultural, genetic, physiological and psychological factors (World Health Organization [WHO], 2000). However, this article focuses on the body as a sign, especially the obese body of the woman.

We are based on the evidence that the notion of ' body' goes far beyond its biological concreteness, because the human body transforms (culturally) into a sign that mediates the social interactions of the subject, either through the cultural messages sent by the others, by the institutions, by elements of everyday life, or through the actions of the subject itself in the context of these interactions. Thus, the body assumes an essential role in the processes of internalization of messages of the collective culture in the construction of what becomes the private, individual subject of the context of the personal culture (Valsiner, 2012).

To analyze how obese women deal with daily 'fatphobic' social suggestions about their body in their life trajectory, we are based on the perspective of semiotic cultural psychology (Valsiner, 2012, 2014; Zittoun, 2015) and on the perspective of the dialogical self (Hermans, 2001; Hermans \& HermansKonopka, 2010) considering, specifically, the transformations that occur in the configurations and reconfigurations of the positioning system of the dialogical self.

\section{The Relation between Collective and Personal Cul- ture: Developing Conceptions of Self}

Culture is conceived by cultural psychology as a set of practices and active processes of coconstruction of signs mediated by human beings, which develop both in the intraand inter-psychological plane. The fundamental aspect of the approach (Valsiner, 2014) consists in analyzing the semiotic processes that are typical of the collective culture (shared by the group) and personal culture (original, subjective), which are constituted in a reciprocal way in the activities in which active persons participate in their cultural contexts.
Furthermore, emphasis is given to the set of social norms, limits and suggestions that, in a certain way, tend to channel the trajectories of life and direct the development more in the direction of certain paths than in the direction of others, promoting a cultural channeling (Branco \& Valsiner, 1997).

The dialogical self is in permanent development. Disregarding this development is to stray from the possibility of better understanding its complexity. It is born from an open system characterized by complex multivocality, in the sense that other significant people occupy positions 'within' a polyphonic self, permeated by tensions and ambivalence between the different voices that coexist, maintaining among themselves relations of dominancy and hierarchical subordination (Hermans, 2001; Hermans \& HermansKonopka, 2010; Mattos \& Chaves, 2015; Oliveira, 2016).

To understand the development of the self, it is necessary to investigate how occur and what are the factors involved in the processes of internalization and externalization, in which significances of the collective culture (social group) lead to the construction of personal, original senses (personal culture) and vice versa. In this relation, subjects constantly internalize, in an active way, social values, beliefs, habits and information, reprocess such suggestions and externalize their values and interpretations through actions that reconstruct the collective culture (Mattos, 2016; Valsiner, 2014).

Throughout people's lives, transitions and ruptures happen and are designated as processes of adjustment to new circumstances, often leading to changes (Zittoun, 2015). After a rupture, the sense of continuity of self is reprocessed by means of a constant dialogue between past and future positions. Thus, we infer that experiences such as bariatric surgery, in the case of obese women, may cause changes in the configuration of their dialogical self.

Situations of prejudice, often experienced by obese people, can also be understood as experiences that lead to repositioning of self. These situations may result in a greater or lesser personal adjustment to a specific cultural reality, bringing a greater or lesser degree of suffering because of the dissonance between how the person sees himself or herself and how the other social subjects see this person.

\section{Prejudice and its Psychological Consequences}

Beliefs and values are fundamental constructs that work in the organization of psychological and social processes and phenomena (Bruner, 1997; Valsiner, 2014). Through these constructs, individuals produce meaning for their experiences, promoting the very dynamics of functioning of the motivational system, which can also include the presence of prejudices. Although prejudice is historically thought and discussed by social policies, which leads to the establishment of laws that criminalize prejudiced actions, its genesis is in social interactions and it is in this plane that the phenomenon of prejudice emerges and develops (Branco, 2016). 
Prejudice involves a negative feeling that is addressed to a particular group of people, which foster, in the prejudiced person, a greater tendency to distance and/or effective rejection of social contact with representatives of discriminated groups (Vasconcelos, Gouveia, Souza Filho, Sousa, \& Jesus, 2004).

Lima, Ramos-Oliveira and Barbosa (2017), relating obesity and prejudice, contribute to the discussion by pointing out stereotypes as socially shared belief systems concerning the homogeneous characteristics of individuals of a given social category, whose foundations are found in explanatory theories about the factors that determine the standards of conduct. And what to say when prejudice is practiced in relation to the size of people's bodies? In several cultures, this is the case of the experiences lived by obese subjects, especially women.

\section{Culture, Corporeality and Gender}

The Brazilian context, with regard to the body of its people, has never been in such tension between opposing poles: the population is increasingly fatter. At the same time, its culture features a normative discourse for slim beauty and health.

Despite the social desire for thinness, Brazil and the world are experiencing the phenomenon of growing obesity. We are the 5th country in the world in the number of obese population, with about $17 \%$ of the Brazilian population in this condition (Junges et al., 2017; Ng et al., 2014); this contradiction between discourse and reality is a fertile field for the emergence of discrimination and prejudice, which affect the subjectivity of obese subjects.

This is intensified with the close relation between gender and corporeality. The way society has historically dealt with issues related to corporeality causes a denial of the body, which refers to the fact that we have to conform to socially accepted standards. It is perceived a certain standard to be followed, a certain model of beauty, of socially accepted and desirable behaviors, even more when considering the woman's body (Santos \& dos Santos, 2017).

The issue of the myth of beauty widely diffused by the media discourse affects mainly women, despite the notable differences between the possible practices in groups more, or less, economically privileged. The fact is that women spend much more time in their lives concerned with the body for the maintenance of beauty, youth and thinness, which is understood, by feminist discourse, as a form of alienation (Amaral, 2014).

In the pursuit of a body idealized in the cultural discourse, we come across data that indicate the cultural channeling for the manipulation and standardization of Brazilian bodies. Brazil has become the second country in the number of fitness gyms in the world. In a world ranking on plastic surgeries, the country is first in plastic surgeries performed in the world. In relation to the number of bariatric surgeries performed in the world, Brazil ranks second in the world ranking behind only the USA, with the majority being performed in women (Campos, Ramos, \& Cohen, 2016; May, 2016).

In addition to these numbers it is possible to observe abundant messages transmitted daily by all media about content related to the risk of obesity, as well as diets, cases of weight loss, food reeducation, bullying, surgeries, tips for workout and losing weight, etc. One of the hardest results of this channeling of a specific body type is the psychic suffering of people who do not fit the generalized desire for the ideal body. This suffering begins in the daily life of these people from a very early age.

The 2012 National Survey on School Student Health features data indicating that students who self-classify themselves as "very fat" or "very thin" are much more likely to adopt risky behaviors, such as the consumption of illicit drugs, alcohol, cigarettes and laxatives (or self-induced vomiting) when compared with "normal" students. They are more likely to suffer frequent bullying - especially motivated by their bodily appearance, but also to become active bullies. They are also more likely to feel loneliness, suffer from insomnia, and to be victims of family violence, aggression and injuries (Kubota, 2014).

Crandall and Schiffhauer (1998) point out the social difficulties and pressures that obese people suffer. The authors highlight studies and researches that associate higher weights with lower socioeconomic conditions, suggesting that obese women have more work than women of lower weight to make a good impression on others, in addition to the fact that obese women have more difficulties in making friends.

Considering all of this, it is necessary to question how the Brazilian women feel classified as obese and how the experience of the fat body affects their development of self and their life trajectories. To answer these questions, this article aims to trace and analyze the processes of subjective coconstruction of the experience of obesity, investigate and discuss the characteristics and power of explicit and implicit messages that operate in specific cultural contexts, analyzing their effects on the development of the dialogical self of a woman under follow-up for almost two years when undergoing bariatric surgery.

\section{Method}

The methodology of semiotic-cultural psychology is systemic, qualitative and idiographic, seeking to understand the general from particular cases that are always unique and the singular contexts of human existence. Putting into practice the philosophical idea that the general exists in the particular and vice versa, the idiographic science enables to construct generalizations based on evidence from case studies and seeks to apply such generalized knowledge to new individual cases, considering, however, their original and specific aspects (Valsiner, 2012).

Inspired by the model of equipurpose of trajectories (Sato \& Tanimura, 2016) that highlights the dimension of time in developmental studies when analyzing the processes of movement towards the future (Zittoun \& Valsiner, 2016), we understand that developmental psychology is the science of actions oriented to objectives that transcend the frontier of the present and incorporate the past and the 
future in the development process (Valsiner, Marsico, Chaudhary, Sato, \& Dazzani, 2015). Thus, the issue of time is fundamental in the methodological composition of this research, which assumed a longitudinal perspective.

In the case presented here, the project of undergoing bariatric surgery was interpreted as an experience of possible rupture in the trajectory of the participants' development, and can be considered as a possible bifurcation point in their life trajectories.

\section{Participants}

Six obese women living in the state of Goiás and Distrito Federal, aged 16-40 years, with BMI (Body Mass Index) equal to or above 35 - morbid obesity - and who had concrete plans to undergo bariatric surgery participated in the broader doctoral research. For this article, we selected the case of Solange (fictitious name). Aged 29 years at the beginning of the research, she belonged to the low income socioeconomic class, was black, lived in a middle-sized city in the state of Goiás, weighed 188 $\mathrm{kg}$, ans was $1.67 \mathrm{~m}$ tall, that is, had a BMI $=67$.

\section{Instruments}

Three semi-structured guidelines were used for individual interviews, one for each research time (see next item) whose questions featured content about life history, significant interactions, body type-mediated experiences, and physical, affective and relational changes arising from bariatric surgery. Other instruments, associated with the interviews, were employed, such as images and figures full of messages about female bodies, outline of the life line with important experiences according to the respondent and completion of sentences with contents that evoked experiences or beliefs about obesity, body and significations of self.

\section{Procedure}

Data collection. After initial contact and scheduling, data co-construction occurred with individual interviews with Solange at three times over the period of one year and three months: at Time 1 ( $\mathrm{T} 1$, before bariatric surgery), at Time 2 (T2, two months after the surgery), and at Time 3 (T3, one year after T2).

Data analysis. By means of thorough transcription of the individual interviews, the co-constructed data were analyzed based on analysis of the narrative interview (Jovchelovitch \& Bauer, 2002) and on the data construction-interpretation (Shweder \& Much, 1987). The developmental processes traced were then analyzed based on the methodology proposed by Branco and Valsiner (1997). The methodology of highlight of dynamic positioning of self used by Moreno and Branco (2015) inspired the construction of the system of dialogical self of Solange.

The transcribed data underwent the following path of treatment and interpretation: (1) overall reading of the information obtained at each time; (2) preliminary analysis and highlighting of recurring themes and words at each time (example: care, beauty, prejudice); (3) highlighting of significant experiences involving the obese body (e.g., school experiences); (4) highlighting the other significant people in their lives (e.g., grandmother and cousins); (5) integrative rereading of all the information obtained at the three research times; (6) survey of the predominant positioning of self (e.g.: I-too fat); (7) construction of the figure of the dialogical self system highlighting the emergencies and maintenance of positions over the time of the research; and (8) construction of the timeline figure.

The results enabled access to Solange's subjective comprehension of her own history and development, with emphasis on the relevant aspects of her life history and on the body-mediated socialization processes, considering the co-construction of significations of self and the development of the participant's self.

\section{Ethical Considerations}

This research project was submitted and approved on December 10, 2014 under CAAE no. 38811114.0.0000.5540 and validation no. 105533/2014, through Plataforma Brasil (Ministério da Saúde, Conselho Nacional de Saúde, Comissão Nacional de Ética em Pesquisa - CONEP) to the Research Ethics Committee of the Instituto de Ciências Humanas of the Universidade de Brasília.

\section{Results}

Considering the issue of irreversible time in this work was essential to the study of development. Reflective capacity and imaginative resources mobilized at three different times of Solange's life trajectory enabled us to trace and analyze important aspects of the dynamic movement of her positions of self, in terms of the configuration of her dialogical self system. It enabled us to highlight the power of the messages that are explicit and implicit in specific cultural contexts and how the interaction through her obese, or less fat, body, with other significant social subjects at the three times contributed to changes and stabilities in her dialogical self system. The cultural issue of obesity in the configuration of fatphobia was also an important result in the report of her life history.

Solange, a 29-year-old black and morbid obese woman, single and unemployed, lived with her grandmother and her uncle, and quit school in the middle of the ninth grade. Her history synthesizes almost all the negative predictions found in studies on the deleterious effects of obesity on a person's life experience. Solange presented a very negative conception of herself.

\section{Changes and Permanencies of Positions of Self}

A resource that proved to be efficient in the study of the development of the conceptions of self was to trace in the interviews of Solange her dynamic positions of self (DPS) 
(Moreno \& Branco, 2015; Roncancio \& Mattos, 2019), which allowed the analysis of which DPS emerged, were maintained or lost/gained strength over the time of the research.

Thus, it was possible to construct configurations of her dialogical self system, highlighting the main alterities (other significant subjects) in relation to the positions, and her projections for a future self. In a schematic manner, her system of self developed between $\mathrm{T} 1$ and $\mathrm{T} 3$ : total predominance of the position "I-fat" at (T1) $\rightarrow$ "I-fat" in dialogical coordination with other positions such as "I-after surgery" and "I-thin in the future (imagined)" at (T2) $\rightarrow$ "I-fat" in dialogical coordination with "I-less fat" and "I-thin in the future (imagined)" at (T3).

At $\mathrm{T} 1$, the only position detected in her dialogical self was "I-fat", associated with seeing herself as ugly and rejected. In Solange's life trajectory, the lived experiences mediated by her obese body were strong and negative, which led to the emergence of a strengthened and predominant DPS for her negative perception (I-fat) and mediating her worldview and interaction with the world. This DPS, still present in the course of all the research, even losing space with new emegences and experiences mediated by weight loss, indicated that this conception of self was stable in Solange's system of self.

At $\mathrm{T} 2$, bariatric surgery proved able to generate certain changes in her conceptions of self, with the emergence of two new positions called "I-after surgery" and "I-thin." "I-after surgery" enabled Solange to establish healthier interactions with important alterities, and the emergence of "I-thin in the future" came associated with several plans and hopes. At T3, being much less thin than she imagined, Solange kept the positions "I-fat" and "I-thin in the future," replaced the position "I-after surgery" with "I-less fat", but the hopes of a thin and happy self in the future became lower.

These positions, at T3, showed that, one year after the impact of surgery and with less than expected weight loss, there were changes in the positions of her system of dialogical self, but her conceptions, perceptions of self, finally, her position as fat shows that the experience and deep internalization of the sign "ugly and obese body" still resists and tends to prevail. In Solange, the internalization of the fatphobic messages received throughout life was powerful and all other significant subjects to the participant grandmother, cousins, relatives and colleagues - contributed to this, strongly affecting her experiences of life.

\section{The Other Significant Subjects}

Investigating the possible origin of Solange's feelings of less value, we see that these emerged as a result of the combination of experiences in the family and in the school, where, as adolescent, she had affective interests in boys, which were systematically frustrated. She quit school, gave up studying and began to have true aversion to social contact. In remembering her history, Solange brings evidence that her feelings of less value and shame to interact with others were not necessarily predominant in her whole life, because they really intensified in adolescence.
In adolescence, the experiences in school contributed significantly to the internalization of fatphobia. In her words, "I was too excluded, I stood in the corners, alone. I was really very excluded!" In another part of the interview, she says "I put that in my head, that no one talks to me because I'm fat, because I'm ugly." The experience of being rejected was so strong that Solange quit school. This series of negative interactions strengthened the internalization of very negative self positions directly associated with the size of her body. Such interactions caused a shift from a life that she assessed as carefree and quiet to a phase of acute suffering and rejection.

According to her, strangers in school and on the street would harass her because of her size. Additionally, family members continually transmitted messages of repudiation to her body. She says, for example, "even in the family! I have an uncle that hugs cute nieces, kisses them. With me, he barely looks at me, barely talks, barely hugs, you know! After I had the surgery". "Ah, now I'll hang with you, because I was going to be "the hot one'."

Solange's grandmother over and over again told her she ate too much. Her cousins wanted to help her by indicating the surgery, and her uncles insisted she would be happier being thin. The messages of 'care' and/or 'repulse' of her family occurred systematically in a direct and indirect way. In short, the most affectively important people discriminated against her or interfered with her so she would change her body unacceptable to them -, and the strangers, on the streets, treated her in a hostile manner. Moreover, in the daily life clothes did not fit her, the chairs on which she sat broke and spaces, like the seats of buses, were not enough for her fat body, which caused profound shame and intimidation on her.

\section{Fatphobia: the Ubiquitous Prejudice}

Solange centralized all of her biographical construction in the periods of her life that were negatively mediated by her obese body and, thus, fatphobia gradually constituted the basis of her dialogical self system: "people like us who are fat like this, don't have much joy like, inside, no we don't." The recurring cultural suggestions about how she should perceive herself (feeling bad because she is fat), present in social interactions and cultural messages she internalized, strengthened the preponderant role of prejudice (fatphobia) in the subjective universe of the participant. She showed strong prejudice against herself - "I have prejudice against myself" - throughout the research.

According to the theory of the affective fields of Valsiner $(2012,2014)$, affectivity has an important regulatory role in human development and in configuration of self. According to the author, prejudices are hypergeneralized signs impregnated with affection, like values, and are deeply rooted in the affective dimension of the dialogical self. Solange's narrative, impregnated with paralinguistic demonstrations and associated with non-verbal indicators, made clear the widespread presence - in her interpersonal interactions - of this prejudice against fat people, prejudice that she began to have against herself. 
No report on the issues of being fat in her trajectory was more striking than Solange's experiences in public transportation. It is on the bus that her greatest fears come true. The bus is a concrete example of a world that refuses to adapt to different body sizes. With the change in the size of the turnstiles that took place a few years ago (attempts by companies to prevent people from passing under the turnstile, or even more than one person at a time), space was reduced to a size that prevents the obese from using the regular path when they take the bus. She is forced to enter through the back door, or to descend through the front door, which evidences her corporality. She says, "They've already harassed me, like you fat, you can't even go through the turnstile!" Buses, like other spaces, are not designed to include plural bodies.

It is interesting to realize the heterogeneous cultural messages that this public space carries. The same space that does not adapt to the obese body, ambiguously and because of laws, has reserved (but not adapted) seats for obese individuals. She also does not fit in the seats. Riding the bus, like that, is to give prominence to your body and give voice to the spaces/social environments that tell you "you must be of a specific size!". That which may have arisen as an idea of "inclusion" was signified by Solange as a form of exposure and embarrassment, and she explains: "I occupy them all and I am embarrassed... I'm afraid the others will complain then I don't even use them..."

With the emergence of the "I-after surgery" position, Solange finds strength to resist the perceptions of judgment that she suffers. At T2, Solange says that she started leaving home and, in relation to the looks she receives, she says that "I've already had the surgery, I will lose weight. I think this thing of having had the surgery and knowing that I will lose weight has helped me a lot to stop with such nonsense." Having undergone the surgery enabled the emergence of a new position, a confidence in herself and in her future that previously did not exist.

By being able to situate herself in the near future with a different body, an imagined body that will be accepted by her and others, a new field emerges, the "I-thin," which, in her imagination, will be able to minimize, neutralize and solve the sufferings caused by aggressions derived from fatphobia. She achieves that through a semiotic affective positioning projected in an anticipated, imagined future, but which presented important effects at present time (at T2).

Even being thinner, the positions "I-fat," "I-less fat," and "I-thin" (in the imagined future), observed especially at T3, seemed to be in constant tension. When asked, for example, about what has not changed, Solange says "single," and thus shows in a single word a whole series of beliefs about affective and sexual relationship associated with body type that still persist.

It is in a kind of ambivalence between liking and not liking herself that Solange finishes at T3 her participation in the research, showing that the way to liking herself can still be long and tortuous. However, the effects observed at the present (T3) of a thin body in the imagined future, through mechanisms of feed-forward type (Zittoun \& Valsiner, 2016), resignify to her the time she is living and open, for her, good perspectives in that direction.

\section{Discussion}

We elect the body as a focal element and a starting point for understanding human development in its collective and individual transformation and construction. Consistently with the theoretical framework, we defend the body as a sign, and here we saw that, in its semiotic status, the body deserves to be interpreted as a dimension that constitutes the subjectivity. It is determined by cultural dynamics and assumes different possibilities of expression and meaning, which change according to the context and the time that surrounds it (Costa \& Silva, 2012).

With regard to the body, conceived as a fundamental and relevant sign for the development of the dialogical self, we have seen that the Brazilian collective culture channels the value of the thin body as the desired, desirable and expected body, especially in relation to women. Based on the results of the research, we could understand how the everyday interactions reported by Solange tend to be mediated by the most evident visual stimuli. Solange recognized and interpreted - at several moments in the interviews - that many of her constitutive experiences occurred because she was fat. We can infer that the body is, indeed, an important sign that mediates cultural and social experiences and, in the specific context of the study, the fat body was negatively highlighted in this regard.

Another possible reflection refers to the phenomenon of internalization and externalization, which are coconstructive processes in which significations of the collective culture lead to the construction of personal meaning and vice versa (Valsiner, 2014). Individuals appropriate such suggestions in their internal, subjective domain and certain meanings associated with these suggestions become part of their subjectivity (Valsiner, 2012, 2014).

In the case of Solange, we have the internalization of the expectations of the collective culture as to the perfect body, generating different positions of self, but, in principle, generating much frustration and suffering because she does not correspond to these expectations. She believes that she cannot be desired or loved, blaming herself for the gluttony and lack of control, gives voice and importance to the looks and interventions of strange others and agrees that she herself must refrain from social life, all because she is fat. Suffering is the affection that represents her.

Regarding the identitary processes, the various transitions and ruptures in her life trajectory, such as school dropout and bariatric surgery, led to repositioning as to the roles assumed by Solange. In the course of existence, such ruptures and transitions have generated processes of adjustment to the 
new circumstances and, often, certain ruptures have led to important changes in the cultural context (Zittoun et al., 2013).

From the cultural perspective, human development is intimately related to the socialization processes, organized and put into practice within cultural contexts. In these contexts, people use physical and semiotic resources, mobilizing instruments, actions and meanings that work in the permanent co-construction between the subject and the culture (Valsiner, 2012). With her body rejected by the current aesthetic standard, Solange, by sharing her history and life trajectory, showed how the conceptions of self, derived from the positions assumed, were affected by the experiences mediated by the body.

This study indicated that the choice for the investigation of life trajectories, in addition to the theoretical-methodological contributions, helped in understanding how women, by signifying their experiences, past experience and expectations for the future, signified themselves and relevant life situations that occurred due to their obesity. This also enabled us to analyze the multiple factors contributing to the construction of prejudices and determine the impact, on the development of self, of the experiences caused by the daily suffering of being different from what is expected, from what is culturally imposed.

Beyond defending or attacking, psychology is expected to seek a semiotic resignification for constructive, positive promotion of the dialogical self of people today discriminated against due to their current weight. This issue allowed us to analyze the multiple factors that contribute to the construction of prejudices and what is the impact, on the development of self, of ruptures caused by the daily suffering of being different from what is socially accepted.

Considering the idiographic nature of the study, we believe that we have contributed to the construction of knowledge on the subject in question, achieving the research objectives. Researches such as the one reported here are aimed at contributing to the advancement of knowledge in psychology, still restricted to some aspects of obesity as symptom, disease or adherence to treatment. However, it is necessary to collaborate especially with psychologists and health professionals who work to promote human development and well-being, through the promotion of the mental health of people who are target of prejudices. It is unacceptable to continue, as professionals, to accept or disregard the power of the normalizing and violent discourse of culture in relation to the obese body, found in the macro (ideal body culture), medium (public spaces as buses) and microgenetic spheres, when someone is the object of joke or disqualification because of being fat. The subject of obesity is fruitful and is not exhausted here, and scientific psychology needs to assume the investigation of the theme adopting a critical stance as to phenomena like this, which generate prejudice and discrimination and oppose the notion of diversity, freedom and democracy.

\section{References}

Amaral, M. (2014). Culto ao corpo e estilo de vida: Práticas estéticas e magreza entre mulheres [Body worship and lifestyle: Aesthetic practices and thinness among women]. In C. Stevens, S. R. Oliveira, \& V. Zanello (Orgs.), Estudos feministas e de gênero: Articulações e perspectivas [Feminist and gender studies: Articulations and perspectives] (pp. 133-148). Florianópolis, SC: Mulheres.

Branco, A. U. (2016). Crenças e práticas culturais: Coconstrução e ontogênese de valores sociais [Beliefs and cultural practices: Co-construction and ontogenesis of social values]. Pro-Posições, 17(2), 139-155. Retrieved from http://periodicos.sbu.unicamp.br/ojs/index.php/ proposic/article/view/8643632

Branco, A. U., \& Valsiner, J. (1997). Changing methodologies: A co-constructivist study of goal orientations in social interactions. Psychology and Developing Societies, 9(1), 35-64. doi:10.1177/097133369700900103

Bruner, J. (1997). Atos de significação [Acts of significance] (S. Costa, Trad.). Porto Alegre, RS: Artes Médicas.

Camic, P. M., Rhodes, J. E., \& Yardley, L. (2003). Qualitative research in psychology: Expanding perspectives in methodology and design. Washington, DC: American Psychological Association.

Campos, J. M., Ramos, A. C., \& Cohen, R. (2016). The importance of Brazilian Society of Metabolic and Bariatric Surgery and its interaction with the XXI World Congress of IFSO in Brazil. ABCD: Arquivos Brasileiros de Cirurgia Digestiva, 29(Supl. 1), 1-2. doi:10.1590/0102-6720201600S10001

Chen, V., \& Pearce, W. B. (1995). Even if a thing of beauty, can a case study be a joy forever? A social constructionist approach to theory and research. In W. Leeds-Hurwitz (Ed.), Social approaches to communication (pp. 135154). New York, NY: Guilford.

Costa, M. T. M. S., \& Silva, D. N. H. (2012). O corpo que escreve: Considerações conceituais sobre aquisição da escrita [The body that writes: Conceptual regards about writing acquisition]. Psicologia em Estudo, 17(1), 55-62. doi:10.1590/S1413-73722012000100007

Crandall, C. S., \& Schiffhauer, K. L. (1998). Anti-fat prejudice: Beliefs, values, and American culture. Obesity Research, 6(6), 458-460. doi:10.1002/j.1550-8528.1998.tb00378.x

Gillespie, A., \& Zittoun, T. (2015). Social and psychological movement: Weaving individual experience into society. In B. Wagoner, N. Chaudhary, \& P. Hviid (Eds.), Integrating experiences: Body and mind moving between contexts (pp. 279-294). Charlotte, NC: Information Age.

Hermans, H. (2001). The dialogical self: Toward a theory of personal and cultural positioning. Culture \& Psychology, 7(3), 243-281. doi:10.1177/1354067X0173001 
Hermans, H., \& Hermans-Konopka, A. (2010). Dialogical self theory: Positioning and counter-positioning in a globalizing society. New York, NY: Cambridge University Press.

Jovchelovitch, S., \& Bauer, M. W. (2002). Entrevista narrativa. In G. Gaskin \& M. W. Bauer (Orgs.), Pesquisa qualitativa com texto, imagem e som: Um manual prático [Qualitative research with text, image and sound: A practical manual] (P. Guareschi, Trad., pp. 90-113). Petrópolis, RJ: Vozes.

Junges, V. M., Cavalheiro, J. M., Fam, E. F., Closs, V. E., Moraes, J. F., \& Gottlieb, M. G. (2017). Impact of Rouxen-Y Gastric Bypass Surgery (RYGB) on metabolic syndrome components and on the use of associated drugs in obese patients. Arquivos de Gastroenterologia, 54(2), 139-144. doi:10.1590/s0004-2803.201700000-11

Kubota, L. C. (2014). Discriminação contra os estudantes obesos e os muito magros nas escolas brasileiras [Discrimination against obese and very thin students in Brazilian schools]. Rio de Janeiro, RJ: IPEA. Retrieved from http://www.ipea.gov.br/portal/index. php?option $=$ com_content\&view $=$ article\&id $=21310$

Lima, C. T. D., Ramos-Oliveira, D., \& Barbosa, C. (2017). Aspectos sociocognitivos da obesidade: Estereótipos do excesso de peso [Sociocognitive Aspects of Obesity: Stereotypes of Overweight]. Psicologia, Saúde \& Doenças, 18(3), 681-698. doi:10.15309/17psd180305

Mattos, E. (2016). A mediação semiótica da responsabilidade: Um estudo sobre a construção de valores na transição para a vida adulta [The semiotic mediation of responsibility: A study on the construction of values in the transition to adult life]. Psicologia USP, 27(2), 178-188. doi: 10.1590/0103-6564D20160002

Mattos, E., \& Chaves, A. M. (2015). Becoming professionals: Exploring Young People's Construction of Alternative Futures. In G. Marsico, M. V. Dazzani, M. Ristum, \& A. C. De Souza Bastos (Eds.), In Educational Contexts and Borders through a Cultural Lens: Looking Inside, Viewing Outside (pp. 131-155). New York, NY: Springer.

May, D. M. (2016). Ambulatory anesthesia for cosmetic surgery in Brazil. Current Opinion in Anesthesiology, 29(4), 493-498. doi:10.1097/ACO.0000000000000361

Moreno, M. R., \& Branco, A. M. U. (2015). Dialogical self development in early life: Theory and research. Psicologia: Teoria e Pesquisa, 31(4), 425-434. doi:10.1590/0102-37722015042284425434

Ng, M., Fleming, T., Robinson, M., Thomson, B., Graetz, N., Margono, C., ... Gakidou, E. (2014). Global, regional, and national prevalence of overweight and obesity in children and adults during 1980-2013: A systematic analysis for the Global Burden of Disease Study 2013. The Lancet, 384(9945), 766-781. doi:10.1016/S0140-6736(14)60460-8
Oliveira, M. C. S. L. (2016). The development of the self and the process of hiper-individualization: inquiries to the Dialogical Psychology. Psicologia USP, 27(2), 201-211. doi: 10.1590/0103-6564D20160004

Roncancio, M., \& Mattos, E. (2019) Self-imaging: beyond children's and adolescents' selfimage. Estudios de Psicología, 40(1), 157-185. doi: 10.1080/02109395.2018.1565028

Salvatore, S., Valsiner, J., Simon, J., \& Gennaro, A. (Eds.). (2010). Yearbook of idiographic science (Vol. 2). Roma, Italy: Firera \& Liuzzo.

Santos, R. A., \& dos Santos, L. C. T. (2017). Gênero e corporeidade [Gender and corporeity]. Revista LatinoAmericana de Geografia e Gênero, 8(1), 177-193. doi:10.5212/Rlagg.v.8.i1.0011

Sato, T., \& Tanimura, H. (2016). The Trajectory Equifinality Model (TEM) as a general tool for understanding human life course within irreversible time. In T. Sato, N. Mori, \& J. Valsiner (Eds.), Making of the future: The trajectory equifinality approach in cultural psychology (pp. 21-42). Charlotte, NC: Information Age Publishing.

Shweder, R. A., \& Much, N. C. (1987). Determinations of meaning: Discourse and moral socialization. In W. M. Kurtines \& J. L. Gerwirtz (Eds.), Moral development through social interaction (pp. 197-244). New York, NY: Wiley.

Valsiner, J. (2012). Fundamentos de psicologia cultural: Mundos da mente, mundos da vida [Fundamentals of cultural psychology: Worlds of the mind, worlds of life] (A.C.S. Bastos, Trad.). Porto Alegre, RS: Artmed.

Valsiner, J. (2014). An invitation to cultural psychology. London, United Kingdom: Sage.

Valsiner, J., Marsico, G., Chaudhary, N., Sato, T., \& Dazzani, V. (Eds.). (2015). Psychology as the science of human being: The Yokohama Manifesto. New York, NY: Springer.

Vasconcelos, T. C., Gouveia, V. V., Souza Filho, M. L. D., Sousa, D. M. F. D., \& Jesus, G. R. D. (2004). Preconceito e intenção em manter contato social: Evidências acerca dos valores humanos [Prejudice and intention to maintain social contact: Evidence about human values]. Psico-USF, 9(2), 147-154. doi:10.1590/S1413-82712004000200005

World Health Organization. (2000). Obesity: Preventing and managing the global epidemic. Geneva, Switzerland: WHO.

Zittoun, T. (2015). Imagining one's life: Imagination, transitions and developmental trajectories. In S. M. G. Gondim \& I. D. Bichara (Orgs.), A psicologia e os desafios do mundo contemporâneo [Psychology and the challenges of the contemporary world] (pp. 127-153). Salvador, BA: Edufba. 
Zittoun, T., \& Cerchia, F. (2013). Imagination as expansion of experience. Integrative Psychological and Behavioral Science, 47(3), 305-324. doi:10.1007/s12124-013-9234-2

Zittoun, T., \& Valsiner, J. (2016). Imagining the past and remembering the future: How the unreal defines the real. In T. Sato, N. Mori, \& J. Valsiner (Eds.), Making of the future: The trajectory equifinality approach in cultural psychology (pp. 3-19). Charlotte, NC: Information Age Publishing.

Zittoun, T., Valsiner, J., Vedeler, D., Salgado, J., Gonçalves, M. M., \& Ferring, D. (2013). Human development in the life course: Melodies of living. Cambridge, United Kingdom: Cambridge University Press.

Milena Oliveira da Silva is a Professor of the Centro Universitário de Brasília, Brasília-DF, Brazil.

Angela Uchoa Branco is a Professor of the Universidade de Brasília, Brasília-DF, Brazil.

\section{Authors' Contribution:}

All authors made substantial contributions to the conception and design of this study, to data analysis and interpretation, and to the manuscript revision and approval of the final version. All the authors assume public responsability for content of the manuscript.

Received: Mar. 22, 2017

1st Revision: Aug. 09, 2017

Approved: Mar. 27, 2018

How to cite this article:

Oliveira-Silva, M., \& Branco., A. U. (2019). Obesity, prejudice, self, and culture: A longitudinal case study. Paidéia (Ribeirão Preto), 29, e2926. doi:http://dx.doi.org/10.1590/1982-4327e2926 